\title{
Announcements
}

\section{Geological Society of India \\ Bengaluru}

\section{Annual General Meeting - 2017}

and

\section{National Seminar on "Deccan Volcanism and Biotic Events across the K-T Boundary"}

The Annual General Meeting (AGM) of the Geological Society of India for 2017 will be held on 26 October at Dr. Harisingh Gour Vishwavidyalaya (a Central University, formerly University of Saugar), Sagar. A National Seminar on "Deccan Volcanism and Biotic Events across the K-T Boundary" is being organized by the Department of Applied Geology, Dr. H.S. Gour Vishwavidyalaya during 26 - 28 October 2017. The seminar will cover the following focal themes:

- Petrology and geochemistry of Deccan volcanics and associated sedimentaries

- Paleontological proxies and paleoenvironmental analyses

- Case studies across the $\mathrm{K} / \mathrm{T}$ boundary in the subcontinent

- Paleomagnetic studies across the K/T boundary

- Future scope of studies across $\mathrm{K} / \mathrm{T}$ boundary

Registration and Abstract Submission are EXCLUSIVELY ONLINE. The conveners, Prof. R.K. Trivedi and Prof. P.K. Kathal may be contacted for any queries. E-mail: pkkathal@rediffmail.com; ktb17_sgr@rediffmail.com, rkt_sagar@hotmail.com

Fellows interested in participating in the seminar can contact Shri R.H. Sawkar and Smt. K.S. Godhavari, Secretaries, Geological Society of India, No.63, $12^{\text {th }}$ Cross, Basappa Layout, Gavipuram, Bengaluru - 560 019; Telefax: 080-2661 3352, Phone: 080-2242 2943; E-mail: gsocind@gmail.com. Web: www.geosocindia.org

\section{Special Issue on}

\section{Artificial Water Reservoir Triggered Earthquakes at Koyna, India}

Under some favorable geological conditions, filling of artificial water reservoirs can trigger earthquakes. The M 6.3 Koyna earthquake of December 11, 1967 is the largest artificial water reservoir triggered earthquake globally. The Koyna region continues to be seismically active and as of now 22 earthquakes of $M \geq 5.0$; and over 200 earthquakes of $M \geq 4.0$ and several thousand smaller earthquakes have occurred in the region. These earthquakes occur in a small area of $20 \mathrm{~km} \times 30 \mathrm{~km}$, are shallow (most events between $2 \mathrm{~km}$ to $7 \mathrm{~km}$ depth), and there are no other earthquake sources within $50 \mathrm{~km}$ of Koyna region. This makes the region extremely suitable for near source study of earthquakes. The question of setting a borehole observatory to investigate triggered earthquakes was discussed in two International Continental Drilling Program (ICDP) Workshops. These workshops very strongly supported setting up of the borehole laboratory. The drilling of the first pilot borehole of $3 \mathrm{~km}$ depth has just started.

In December 2017, we shall be completing fifty years of the December 1967 Koyna earthquake. It is proposed to dedicate the December 2017 issue of the Journal of the Geological Society of India to Koyna earthquakes. Contributions are invited on geology/geophysics related issue of earthquakes at Koyna. Please submit your manuscript not exceeding 6000 words including diagrams (a full page diagram is equivalent to 1300 words, and a one-half page equivalent to 700 words) on the format of the Journal of the Geological Society of India to the Guest Editor, Prof. Harsh K. Gupta (E-mail: harsheseg@gmail.com) on or before 31 st May 2017. All manuscripts shall undergo usual review process. 